\title{
THE DEVELOPMENT OF MODULE TO INCREASE CRITICAL THINKING SKILL
}

\author{
Fertilia Ikashaum ${ }^{1}$ \\ ${ }^{1}$ Institut Agama Islam Negeri Metro \\ 1ikashaum@gmail.com
}

\begin{abstract}
Abstrak
Penelitian ini bertujuan untuk mengetahui bagaimana mengembangkan modul matematika serta efektifitasnya ditinjau dari kemampuan berpikir kritis matematis siswa. Subjek penelitian adalah siswa kelas VII SMP IT Bina Insani Metro. Penyusunan modul dilakukan berdasarkan panduan penyusunan modul dari Depdiknas 2008. Hasil validasi menunjukkan bahwa modul telah memenuhi standar kelayakan isi, media, dan bahasa. Hasil uji coba awal menunjukkan bahwa modul termasuk dalam kategori baik. Hasil uji terbatas dalam penelitian ini berupa modul matematika pada materi segitiga dan segi empat. Data penelitian diperoleh melalui tes berpikir kritis matematis. Hasil uji efektivitas menunjukkan siswa telah memenuhi kriteria ketuntasan minimal dalam kemampuan berpikir kritis matematis.
\end{abstract}

Kata kunci: berpikir kritis, modul

\begin{abstract}
This research aimed to find out how to develop mathematics modules and its effectiveness in terms of critical thinking skills of mathematics. The subject of this research was students of VII ${ }^{\text {th }}$ grade of SMP IT Bina Insani Metro. The preparation of the module was done based on the guidelines on programming modules from Depdiknas, 2008. The result of validation indicate that the module has a standard feasibility of content, media, and languages. The results of the initial trials showed that the modules included in well category. The result of limited tests in this study was a math module on triangles and rectangles materials. The research data was obtained by the test of mathematical critical thinking. The results of effectiveness showed that students have completed a minimum standard in the ability of critical thinking of mathematics.
\end{abstract}

Keywords: critical thinking, module

Citation: Ikashaum, F. 2019. The Development of Module to Increase Critical Thinking Skill. Matematika dan Pembelajaran, 7(2), 22-30. DOI: http://dx.doi.org/10.33477/mp.v6i2 


\section{INTRODUCTION}

Critical thinking is required in the learning process that requires problem solving skills, one of them in the math lesson. This is supported by (Ebiendele Ebosele Peter, 2012) which states that students who have critical thinking skills can solve the problem effectively. (Beyer, 1995) states that critical thinking is needed to ensure a problem can be specifically defined in order to obtain some of the criteria as a reference for resolving the issue. From the opinions it can be attributed to the importance of critical thinking in learning, that is as a tool for students to reason in finding solutions to a problem by considering various possibilities. Thus, critical thinking becomes an important thing as a benchmark of the development of the thinking of students.

Critical thinking skills included in the purpose of mathematics learning (Depdiknas, 2006), but this is not supported by the facts that exist in Indonesia. To respond the purpose of mathematics learning that has not been achieved and contained in the legislation, one way to do is to apply self-regulated in students' learning process. Self-regulated learning is the development of constructivist theory which suggests that understanding of learning more emphasis on the process rather than results. To emphasize the process of constructivism in a selfregulated learning, it is need a teaching materials that are easy to use by teachers and accordance with the conditions of students. Therefore, in an effort to improve the quality of mathematics instruction that supports self-regulated learning of students, one of the ways that can be done is innovation in the use of teaching materials. However, the teaching materials has not been optimal because students are still using teaching materials that are less motivating them to learn independently.

Results of interviews to teachers of mathematics showed that students used to learning according to the guidelines of teachers in the classroom. Focus attention attention of this interview is the use of mathematical teaching materials that do not involve students in developing their capacity of thinking. In addition to Student Worksheet (LKS), it is also used Curriculum 2013 books. However, some teachers feel the composition of the materials and concepts are difficult to apply 
in learning. The results of several trials of using K13 textbooks to students also showed similar results, that is the difficulty of students in understanding composition material. In addition, the way of presenting the issues presented in the book is less supportive of the students to understand the issue of desirability.

Furthermore, in another book that is used there is still a false mold and for several subsequent editions, printed the same error still occurs. Student worksheet containing more exercises of the provided formula so that students can easily resolve the matter, but students' understanding of concept does not already maximized. Giving materials are also less familiarize students to find their own concepts of mathematics so that students become dependent on teachers to develop these concepts.

There is a printing error, the students are also less motivated to use another book as an additional source for their independent study. In the classroom, teachers usually using question and answer method to make students active, but it cannot ensure that the student has understood concepts. Thus, when the initial learning students can not be ascertained understand the desired concept, for further learning students tend to not pay attention to the teacher's explanation.

Another thing that is found in this interview is that students just do the questions provided in the book after being asked by the teacher in the classroom. As a result, student will work on the problem if the teacher has explained the material first. Although the learning process still happen, but the role of the teacher is very large by this method.

In terms of critical thinking skills, the use of text books for teachers are less effective if it is used to develop such capabilities. This is because the textbook refers to the ability of conceptual understanding and problem solving. In addition, because it is used simultaneously, these textbooks are less appropriate when applied in each of these areas, especially if the teacher wants to develop certain abilities. As a result, textbooks are not communicative and do not solicit feedback from readers (Nasution, 2016). Given the needs of students of each region is different, it is also necessary text books in accordance with the development needs of students who use it. 
Based on this background, the selection of teaching materials become important things a teacher. Among the teaching materials are often used, the module becomes a very good option to be developed. This is because the module can be hold students in independent study, given the speed of learning of each student are not the same. Students who have a good comprehension can achieve learning goals quickly as desired teacher. While students who have a good grasp of the less can equate learning with his speed through the process of reading at home.

One of the strategies in reading comprehension strategy is PQ4R (preview, question, read, reflecty, Recite, review). This strategy is used to help students remember what they read and help the learning process in the classroom reading activities carried out by the module. This is according to research (Ulfa, 2019) which indicates that learning with the PQ4R strategy is effective in increasing the ability to understand students' mathematical concepts. Similar results are also shown by research (Wardani, 2019) which shows that there is an increase in learning activities and students' mathematical problem solving abilities using the PQ4R strategy. From the above description, we need a study to develop modular teaching materials so as to enhance students' critical thinking skills.

\section{METHOD}

This subject is divided into several stages of research. The subject of a preliminary study is teacher with a class VII. Subject module validation is a lecturer at the faculty of Mathematics Department of Mathematics, University of Lampung and professor of informatics techniques IBI Darmajaya Bandarlampung. The field trials carried out by five seventh grade students who do not take the matter triangles and rectangles, whereas the subject field tests are all students of class VII A.

This research is a research and development (research and development) that follows the steps Borg \& Gall and refers to the procedure (Sanjaya, 2013) with some modifications. The steps of this development study is a preliminary 
study, preparation of modules, module validation is continued revision, revision continued field trials and field testing.

When studies are carried out preliminary study guide preparation of modules, syllabi, as well as some types of teaching materials based on the results of interviews. Data were analyzed descriptively as a reference for preparing a module. Furthermore, the preparation of modules based on a needs analysis module follows the guidelines for the preparation of the (Depdiknas, 2006). Modules that are ready then validated by subject matter experts and media experts. Instruments a statement Likert scale with four answer options used and the results were analyzed qualitatively.

Modules that have been validated and revised based on advice from expert lecturers subsequently awarded to five students. Instruments such as Likert scale statement is given to know how legibility, their interest and their response to the module.

After revision based on advice from the subject, conducted a field test to a class of students. In this step the instrument test the critical thinking skills at the end of the lesson. Previously, such instruments are tested to determine the validity, reliability, distinguishing features, and the difficulty level.

(3) data collection techniques and instrument development, and (4) data analysis techniques. Qualitative research must describe the approaches and methods used in research.

\section{RESULT AND DISCUSSION}

Preliminary studies conducted by reference module manufacture based on interviews of teachers who teach in class VII. From the results of these interviews can be concluded that the teaching materials used by teachers in teaching about supporting the development of critical thinking skills. Further analysis of the indicators and material that will be poured in the module. The module content is devoted to the critical thinking skills. The composition of the modules are substantially the outer cover, the opening section, part of the contents, and the concluding section. 
Based on the results of the assessment module by subject matter experts and media specialists, the components provided are categorized as very good. Furthermore, the initial field trials to five students. Components assessed included in the category of display modules, presentation materials, and the benefits of the module. After the third revision included in either category.

The results of field tests of the effectiveness of the modules to facilitate critical thinking skills mathematically demonstrated Sig. $<0.05$ then $\mathrm{H} 0$ is rejected or the percentage of students who use mastery learning based module PQ4R more than $70 \%$. In other words, after learning to use the module using a strategy PQ4R, when learning, critical thinking skills students have already reached the minimum completeness criteria.

Based on the test results the proportion in mind that after learning to use the module, students reach a minimum completeness criteria 65 to test critical thinking skills. This is according to research (M, Yulianti, \& Sutiarso, 2014) which indicates that the module is effectively used in learning because more than $60 \%$ of students pass the study.

Suitability research hypothesis testing decision because during the learning of students familiarized with problems that require exploration capabilities flat wake. Students are also given the material that supports the identification of concepts making it easier to clarify the truth and fix it. In addition, preparation of the module make students interested in it so it does not make them bored when asked to read independently. This is consistent with research (Fidiana, Bambang, \& Pratiwi, 2012) which states that the problems on the module encourages students to read that initiative students for higher learning.

Learning to use the module is not only confined to school, but students can also use the module at home when circumstances permit. This helps students learn mathematics independently. Learn independently gives freedom to the students to choose their own way of learning in accordance with the desired speed and style of learning (Johnson, 2002).

This module was created with the PQ4R strategy to improve critical thinking skills obtained from the standard of validity, practicality, and 
effectiveness of focusing on the stages in understanding reading. The standard is caused by several factors, that is the first factor is formulated based modules PQ4R strategy in accordance with the learning step so as not to cause a gap between the learning process and media used. Second, it presents problems of critical thinking to make students interested in math concepts learned process, because critical thinking to make the students more closely in understanding a concept and can connect with other concepts in general. Through the stages contained in this strategy, the cultivation of concepts in depth makes Mathematics learning more meaningful in students' memories. This is consistent with the results of research (Novalia, 2019) which concluded that students obtain learning independence in learning mathematics through PQ4R strategy.

The highest percentage of critical thinking indicators exist at generalize and indicators with the lowest percentage in the indicator explore. This is because while lowering formula one formula to another, students can easily find them by example in the form of points and questions that they made themselves. This is consistent with the results of research (Jumaisyaroh, Napitupulu, \& Hasratuddin, 2015) and (Lestari \& As'ari, 2013).

As for the indicator explore, students are still difficult to construct meaning in different viewpoints. Research conducted by (Lestari \& As'ari, 2013) and (Pratama \& Ariyanto, 2015) states that explores indicators increased. But in this study, students have a low percentage in exploring a problem. This can be explained from the opinions (Rosnawati, 2012) states that a matter can facilitate critical thinking if the item was the basis of the statement contains a graphic, images, tables, or images. In presenting the matter to load indicator explore, this matter shaped description of the square and the rhombus. As a result, many students do not successfully overcome this problem.

\section{CONCLUSION}

Based on the results obtained empirically concluded that development of mathematics modules starting from preliminary studies, validation expert and media materials, field trials and field testing. Judging from its effectiveness, the 
student has met the minimum completeness criteria in the ability of critical thinking mathematically.

\section{REFERENCES}

Beyer, B. K. (1995). Critical Thinking. Bloomington: Phi Delta Kappa Educational Foundation.

Depdiknas. (2006). Penulisan-Modul Depdiknas 2008. Jakarta: Depdiknas.

Fidiana, L., Bambang, S., \& Pratiwi, D. (2012). Pembuatan dan Implementasi Modul Praktikum Fisika. Unnes Physics Education Journal, 38-44.

Johnson, E.B. (2002). CTL Contextual Teaching \& Learning. Bandung: Kaifa.

Jumaisyaroh, T., Napitupulu, E. E., \& Hasratuddin, H. (2015). Peningkatan Kemampuan Berpikir Kritis Matematis Dan Kemandirian Belajar Siswa Smp Melalui Pembelajaran Berbasis Masalah. Kreano, Jurnal Matematika Kreatif-Inovatif, 157.

Lestari, E., \& As'ari, A. R. (2013). Pengembangan Modul Pembelajaran Soal Cerita Matematika Kontekstual Berbahasa Inggris Untuk Siswa Kelas X. Artikel Ilmiah jurnal-online.um.ac.id.

M, R. D., Yulianti, D., \& Sutiarso, S. (2014). Pengembangan Bahan Ajar Modul Matematika Kelas XI IPA SMA di Bandar Lampung. Jurnal Teknologi Informasi Komunikasi Pendidikan, 1-14.

Nasution, N. A. (2016). Pengembangan Bahan Ajar Berbasis Model Pembelajaran Inkuiri untuk Meningkatkan Kemampuan Komunikasi Matematis dan Self Regulated Learning Siswa SMP Negeri Panyabungan. Medan: Program Studi Pendidikan Matematika Pascasarjana, Universitas Negeri Medan. Tesis: Tidak Dipublikasikan.

Novalia, H., \& Noer, S.H. (2019). Pengembangan Modul Pembelajaran Matematika dengan Strategi PQ4R untuk Meningkatkan Kemampuan Berpikir Kreatif dan Kemandirian Belajar Siswa SMA. Jurnal Penelitian Dan Pembelajaran Matematika, 51-65.

Peter, E. E. (2012). Critical thinking: Essence for teaching mathematics and 
mathematics problem solving skills. African Journal of Mathematics and Computer Science Research, 39-43.

Pratama, F. S., \& Ariyanto. (2015). Peningkatan Kemampuan Berpikir Kritis dan Pemecahan Masalah Matematika Dengan Problem Posing Pada Siswa Kelas VIII Semester II SMP Muhammadiyah 6 Surakarta Tahun 2014/2015. Surakarta: Fakultas Keguruan dan Ilmu Pendidikan, Universitas Muhammadiyah Surakarta. Skripsi: Tidak Dipublikasikan.

Pujawan, I. G. N. (2005). Implementasi Pendekatan Matematika Realistik dengan Metode PQ4R Berbantuan LKS Dalam Meningkatkan Motivasi dan Prestasi Belajar Matematika Siswa SMP Negeri 4 Singaraja. Jurnal Pendidikan Dan Pengajaran IKIP Negeri Singaraja, 774-792.

Rosnawati, R. (2012). Berpikir kritis melalui pembelajaran matematika untuk mendukung pembentukan karakter siswa. Seminar Nasional Pendidikan, 19.

Sanjaya, W. (2013). Penelitian Pendidikan Jenis Metode dan Prosedur. Jakarta: Kencana.

Ulfa, M. (2019). Strategi Preview, Question, Read, Reflect, Recite, Review (PQ4R) Pada Pemahaman Konsep. Mathema Journal, 48-55.

Wardani, R.K. (2015). Upaya Peningkatan Aktivitas Belajar dan Kemampuan Pemecahan Masalah Matematika Siswa Melalui Penerapan Model Kooperatif Tipe Kancing Gemerincing Dengan Strategi Pembelajaran PQ4R (Preview, Question, Read, Reflect, Recite, Review) Pada Siswa Kelas VIII. Surakarta: Fakultas Keguruan dan Ilmu Pendidikan, Universitas Sebelas Maret. Tesis: Tidak Dipublikasikan. 